\title{
Natural Occurrence of Microsphaera pulchra and Phyllactinia guttata on Two Cornus Species
}

Leigh Ann Klein, Graduate Research Assistant, and Mark T. Windham, Associate Professor, Department of Entomology and Plant Pathology; and Robert N. Trigiano, Professor, Department of Ornamental Horticulture and Landscape Design, The University of Tennessee, Knoxville 37901-1071

\begin{abstract}
Klein, L. A., Windham, M. T., and Trigiano, R. N. 1998. Natural occurrence of Microsphaera pulchra and Phyllactinia guttata on two Cornus species. Plant Dis. 82:383-385.

Powdery mildew has become a common foliar disease of Cornus florida and other dogwood species in the eastern United States during the last several years. This study was conducted to determine the identity of powdery mildew fungi on C. florida and C. amomum. Ascocarps of Microsphaera pulchra and Phyllactinia guttata occurred singly and together on both $C$. florida and $C$. amomum leaves. $M$. pulchra ascocarps occurred at a higher density than $P$. guttata ascocarps on $C$. florida leaves, whereas $P$. guttata ascocarps occurred more frequently than $M$. pulchra ascocarps on C. amomum leaves. Histological studies, however, did not provide supplementary data of infection by the powdery mildew species that occurred less frequently on the leaves of each dogwood species. M. pulchra did not penetrate the cells of $C$. amomum, and likewise $P$. guttata did not enter through stomata of $C$. florida leaves. The presence of ascocarps of both species was not the result of infection of the dogwoods by both pathogens. The ascocarps of $M$. pulchra probably became airborne and then settled on the $C$. amomum leaves. Similarly, the ascocarps of $P$. guttata landed on $C$. florida leaves. These results emphasize the importance of correct pathogen identification using several criteria such as ascocarp morphology, host-pathogen relationships, distribution of the pathogen, conidial morphology, and histology.
\end{abstract}

Additional keywords: Oidium, Ovulariopsis, scanning electron microscopy

There are approximately 65 Cornus L. species (dogwoods; 4) distributed throughout the northern hemisphere, with centers of diversity in eastern North America, the Pacific Northwest, eastern Asia, and Central America (10). Flowering dogwood, $C$. florida L., is an understory species native to the deciduous forest in the eastern United States and plays an important role in the ecosystem by providing habitat and food for wildlife (4). Several species of dogwoods are cultivated for their showy bracts, attractive foliage, and fruit and twig color.

Powdery mildews of Cornus spp. were rarely reported before 1994, but have since become a common foliar disease in the eastern United States $(6,9,11,12)$. Dogwood leaves infected with powdery mildew become distorted, have an increase in red pigmentation, and develop lesions that eventually become necrotic. The disease may also cause stunting of young seedlings and slow growth in older trees (12). Nearly $100 \%$ of the foliage may be affected in

Corresponding author: M. T. Windham

E-mail: mwindham@utk.edu

Accepted for publication 2 December 1997.

Publication no. D-1998-0129-01R

(C) 1998 The American Phytopathological Society seedlings and liners, resulting in possible mortality, whereas older, well-established trees generally are not killed by the disease.

Two powdery mildew species have been reported to infect dogwoods in eastern North America, Microsphaera pulchra Cooke and Peck $(1,5,11)$ and Phyllactinia guttata (Wallr.:Fr.) Lév. (2,5,9). The anamorph of Microsphaera spp. (Oidium) was reported on flowering dogwood $(5,6)$, whereas Ovulariopsis, the anamorph stage of Phyllactinia spp., was reported on various Cornus spp. (1). P. guttata is the only species within this genus reported to occur on Cornus spp. $(1,5)$.

C. florida is valued for its pink or white bracts, red fruit, and seasonal red foliage (13). C. amomum Mill., the silky dogwood, is a common blue-fruited shrub found in swampy areas of the eastern United States (4). The purpose of this study was to identify the powdery mildew species infecting C. florida and C. amomum trees that were grown in a research compound on The University of Tennessee Agricultural Campus.

\section{MATERIALS AND METHODS}

Leaf disks were collected from three $C$. florida trees and one C. amomum tree with powdery mildew in the fall of 1996 on The University of Tennessee Agricultural Campus. The dogwood trees were located at opposite corners (11 m apart) of a research tree compound. Disks were cut from the leaves using a 7-mm-diameter cork borer, bisected, then fixed and vacuum aspirated in Histochoice (Amresco, Solon, OH). Leaf samples were then dehydrated with a series of $30,50,70,90,95$, and $100 \%$ isopropyl alcohol each for $30 \mathrm{~min}$. Dehydrated samples were embedded with TissuePrep (Fisher Scientific Co., Fair Lawn, $\mathrm{NJ})$ and cast into blocks. Leaf disks were sectioned at $10 \mu \mathrm{m}$ on a rotary microtome and placed on glass slides. Sections were stained with a modified Flemming's Triple Stain (8). Cover slips were applied with Eukitt Mounting Medium (Calibrated Instruments, Hawthorne, NY) and slides viewed with a Nikon Diaphot compound microscope (Nikon Corp., Tokyo) at 400 to $1,000 \times$ magnification. Photographs were taken with a Nikon N2000 camera using Techpan 2415 film (Eastman Kodak Company, Rochester, NY).

Additional leaves collected from the same $C$. amomum and $C$. florida trees were dried in a plant press. A separate species of powdery mildew was observed on the leaves of each dogwood species using an Olympus SZH10 research stereo dissecting scope (Olympus America Inc., Lake Success, NY) at 40 to $70 \times$ magnification. $P$. guttata was identified on $C$. amomum using number of asci/fruiting body, ascocarp diameter, and form of appendages (1). The powdery mildew observed on $C$. florida, a Microsphaera sp., was identified using asci numbers/ascocarp, form and length of appendages, and ascocarp size. Eight $\mathrm{Mi}$ crosphaera spp. ascocarps, from a total of 3 dried leaf specimens of $C$. florida, were mounted in lactophenol and examined with an Olympus BH-2 compound microscope at 100 to $400 \times$ magnification. The diameter of these 8 ascocarps and the length of 4 to 5 appendages of each ascocarp were measured. The final ratio of appendage length to ascocarp diameter determined the identity of the Microsphaera sp. (1).

Using a 12-mm cork borer, disks were cut from dried leaves of each dogwood species that had both $M$. pulchra and $P$. guttata ascocarps occurring together, and were prepared for scanning electron microscopy without fixation or dehydration. Specimens were mounted on aluminum stubs with double-sided sticky tape, sputter-coated with gold-palladium, then viewed with an ETEC Autoscan (Hayward, 
CA) at 60 to $1,200 \times$ magnification with an operation at $10 \mathrm{kV}$. Photographs were taken on panchromatic Polaroid 4 by 5 instant sheet film (Polaroid Resource Center, Cambridge, MA).

\section{RESULTS}

Dichotomously branched appendages and the presence of many asci in each ascocarp identified one of the powdery mil- dew genera as Microsphaera (1). Species determination was based on the ratio of ascocarp diameters to appendage length. The ratio of ascocarp diameter (92-(107)128) to appendage length (117-(134)-160) was $1: 1.3 \pm 0.14$, which identified the species as $M$. pulchra (1). Bulbous-based appendages and number of asci/ascocarp identified the second powdery mildew species as $P$. guttata (1).

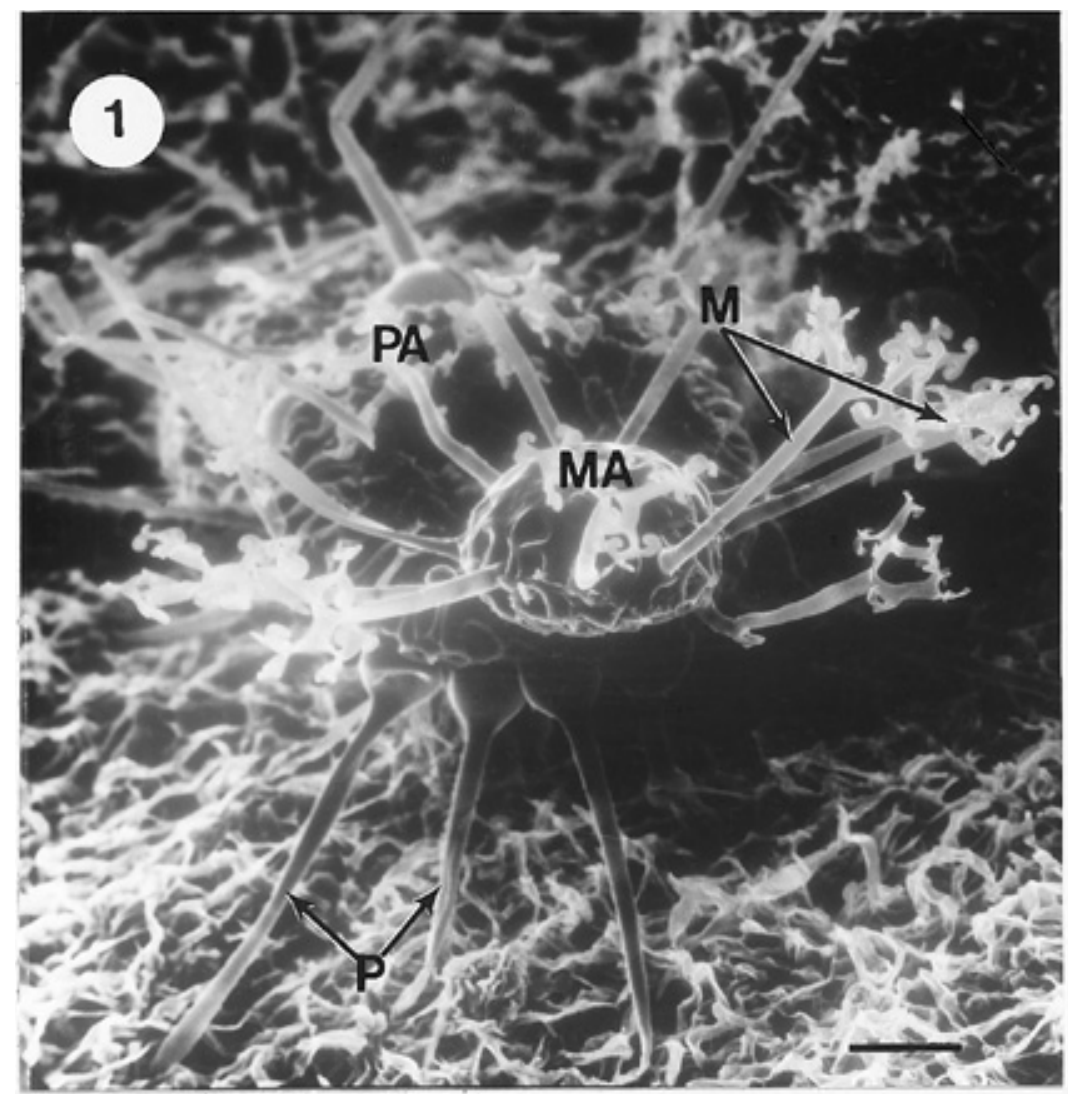

Fig. 1. Powdery mildew on Cornus amomum. Occurrence of Microsphaera pulchra (MA) and Phyllactinia guttata ascocarps (PA) on the abaxial leaf surface. $\mathrm{P}=$ appendages of $P$. guttata; $\mathrm{M}=$ appendages of $M$. pulchra; bar $=55 \mu \mathrm{m}$.
Ascocarps of $P$. guttata and $M$. pulchra were observed on some dogwood leaves (Fig. 1). M. pulchra ascocarps were distributed randomly on the abaxial surface of C. florida leaves and occurred at higher densities than ascocarps of $P$. guttata. $P$. guttata ascocarps were mixed with and in close association with $M$. pulchra ascocarps on these same leaves. In contrast, ascocarps of $P$. guttata were commonly found on $C$. amomum leaves in close association with the less frequently encountered M. pulchra ascocarps. Ascocarps of $M$. pulchra on $C$. amomum were at times directly on the leaf surface and at other times appeared attached to the $P$. guttata ascocarps. However, $P$. guttata ascocarps often were situated on the $C$. florida leaf surface with appendages pointing away from the epidermis.

Histological studies revealed that $P$. guttata hyphae entered the abaxial leaf surface of $C$. amomum through stomatal openings (Fig. 2A). The hyphae ramified throughout the leaf tissue of the host and produced haustoria only in mesophyll cells. M. pulchra hyphae were restricted to the surface of the $C$. florida leaf and penetrated directly, forming haustoria only in the adaxial and abaxial epidermal cells (Fig. 2B). Since penetration through stomata was not observed on $C$. florida leaves, it was assumed that $P$. guttata was not a pathogen of these leaves. Likewise, since direct penetration was not observed on $C$. amomum leaves, it was assumed that M. pulchra did not infect these leaves.

\section{DISCUSSION}

Yarwood (14) cautioned that errors of host-parasite association can be made if ascocarps of powdery mildew fungi become associated with a plant after dissemination. Appendage orientation of Phyllactinia spp. was used to determine the origin of ascocarps on specific leaf surfaces (3).

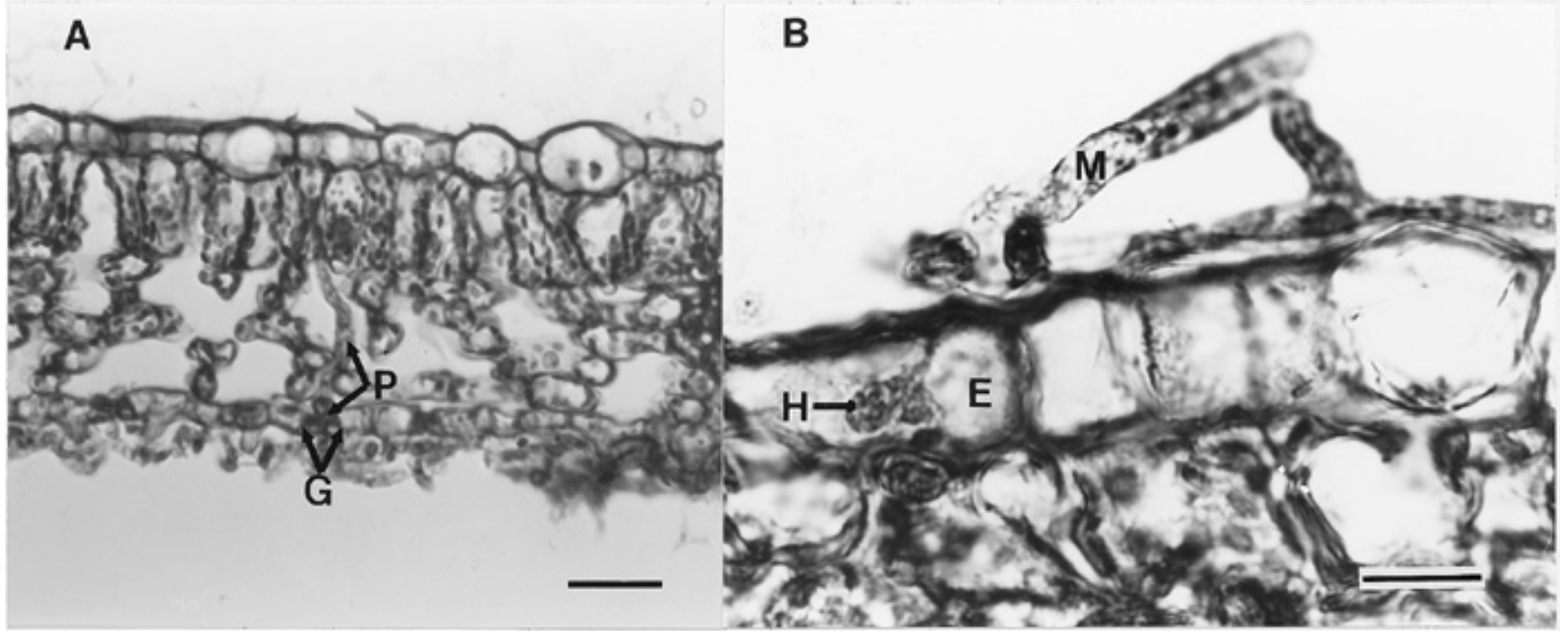

Fig. 2. (A) Penetration of Cornus amomum abaxial epidermal cells by Phyllactinia guttata. $\mathrm{G}=$ guard cells; $\mathrm{P}=P$. guttata hyphae; bar $=12 \mu \mathrm{m}$. $(\mathbf{B})$ Penetration of $C$. florida adaxial epidermal cell (E) by Microsphaera pulchra. $\mathrm{M}=$ M. pulchra hyphae; $\mathrm{H}=$ Haustoria; bar $=13 \mu \mathrm{m}$. 
Phyllactinia spp. have the following two appendage types: bulbous equatorial appendages and branched appendages formed on the crown or apex of the fruiting structure. The bulbous appendages point downward and function to free the mature ascocarp from superficial mycelium on the leaf surface (3). The ascocarp adheres to new surfaces with the apical appendages downward and the bulbous-based appendages arranged so that the tips point away from the surface (3). P. guttata ascocarps on the $C$. florida leaves had bulbous-based appendages pointing away from the leaf surface, which implied the structures were not formed on these dogwoods. M. pulchra appendages appear not to function to lift the ascocarp from host surface. Therefore, histological examination of the infected tissue for the mode of pathogen ingress and colonization of the leaf would be needed to determine if the ascocarp had formed on the leaf.

Histological studies were conducted to determine ingress and colonization by powdery mildew pathogens of each host. The mycelium of Microsphaera spp. is epiphytic, whereas the mycelium of Phyllactinia spp. is hemiendophytic, forming both mycelium on the surface and producing internal hyphae $(1,14)$. The mycelium on the abaxial leaf surface of both dogwood species was profuse, and ascocarps were readily found in the histological sections of the leaves. Hyphae of $P$. guttata entered stomata of the $C$. amomum leaves; however, there was no indication that $P$. guttata hyphae entered the stomata or grew within mesophyllic tissue of $C$. florida leaves. $M$. pulchra directly penetrated the abaxial and adaxial epidermal cells of $C$. florida, but did not infect $C$. amomum. This study provides documentation of both $M$. pulchra and $P$. guttata ascocarps simultaneously occurring on $C$. florida and on $C$. amomum; however, there was no evidence of concurrent infection by both fungi within the same dogwood leaves.

Powdery mildews can be identified using five interrelated criteria. The most conclusive way to identify the pathogen is with ascocarp morphology. However, ascocarps are not formed until late in the fall, if at all, on dogwoods. Previously documented reports of host-pathogen relationships and distribution of the pathogen are useful supplements to ascocarp morphology (7). Throughout the growing season, the conidial stage can be used to identify the pathogen, but environmental conditions may cause variations in the morphology (1). The most accurate technique of identification is histological examination of host tissue that reveals penetration of the leaf cell, morphology and area of haustorial formation, and the area of hypha ramification.

Observations of ascocarps of two powdery mildew species occurring on a dogwood species warrants caution. Several criteria need to be utilized to identify the powdery mildew pathogen of a particular host. Potential differences in the disease processes of Microsphaera and Phyllactinia spp. may have implications to breeding programs in the search for a general resistance mechanism for disease management. Yarwood warned that resistance to one powdery mildew species may not necessarily correlate with resistance to another (14); therefore, correct identification of the pathogen is imperative.

\section{LITERATURE CITED}

1. Braun, E. 1987. A monograph of the Erysiphales (powdery mildews). J. Cramer, Berlin. Beih. Nov. Hedwigia 89:1-700.

2. Burrill, T. J., and Earle, F. S. 1887. Article VI.-Parasitic fungi of Illinois. Pages 387428 in: Bulletin of the Illinois State Laboratory of Natural History, Part II, Vol. II. J. W. Franks and Sons, Peoria, IL.

3. Cullum, F. J., and Webster, J. 1977. Cleistocarp dehiscence in Phyllactinia. Trans. Br. Mycol. Soc. 68:316-320.

4. Eyde, R. H. 1988. Comprehending Cornus: puzzles and progress in the systematics of the dogwoods. Bot. Rev. 54:233-251.

5. Farr, D. F., Bills, G. F., Chamuris, G. P., and Rossman, A. Y. 1989. Fungi on plants and plant products in the United States. APS Press, St. Paul, MN.

6. Hagan, A. K., Gilliam, C. H., Keever, G. J., and Williams, J. D. 1995. Reaction of dogwood selections to powdery mildew. Ala. Agric. Exp. Stn. Res. Rep. Ser. No. 10:24-25.

7. Hirata, K. 1976. Notes on host range and geographic distribution of the powdery mildew fungi, VI. Distribution of the host of powdery mildew fungi in the families of angiosperms. Trans. Mycol. Soc. Jpn. 17:35-62.

8. Johansen, D. A. 1940. Plant Microtechnique. McGraw-Hill Book Co., NY.

9. McRitchie, J. J. 1994. Powdery mildew of flowering dogwood. Plant Pathol. Cir. No. 368. Gainesville, FL

10. Murrell, Z. E. 1993. Phylogenetic relationships in Cornus (Cornaceae). Syst. Bot 18:469-495.

11. Ranney, T. G., Grand, L. F., and Knighten, J. L. 1994. Resistance of Cornus kousa taxa to dogwood anthracnose and powdery mildew. Proc. Southern Nurserymen's Assoc. Res. Conf. 39:212-216.

12. Windham, M. T. 1996. Resistance to powdery mildew in flowering dogwood. Proc. Southern Nurserymen's Assoc. Res. Conf. 41:197-199.

13. Witte, W. T. 1995. Dogwood culture in nursery and landscape. Tenn. Agric. Sci. 175:4751.

14. Yarwood, C. E. 1957. Powdery mildews. Bot. Rev. 23:235-301. 